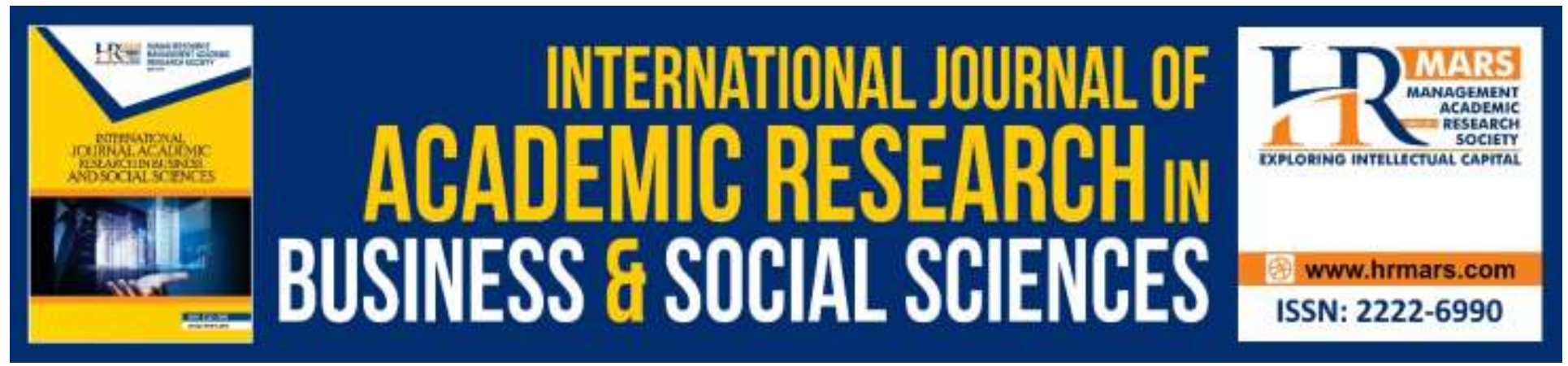

\title{
A Qualitative Case Study on Experiences of Universities and Industries Linkages in Nigeria
}

Ikechukwu Aloysius Odigbo \& Ismi Arif Ismail

To Link this Article: http://dx.doi.org/10.6007/IJARBSS/v9-i11/6704

DOI: 10.6007/IJARBSS/v9-i11/6704

Received: 15 October 2019, Revised: 30 October 2019, Accepted: 12 November 2019

Published Online: 30 November 2019

In-Text Citation: (Odigbo, \& Ismail, 2019)

To Cite this Article: Odigbo, I. A., \& Ismail, I. A. (2019). A Qualitative Case Study on Experiences of Universities and Industries Linkages in Nigeria. International Journal of Academic Research in Business and Social Sciences, 9(11), 1340-1359.

Copyright: (C) 2019 The Author(s)

Published by Human Resource Management Academic Research Society (www.hrmars.com)

This article is published under the Creative Commons Attribution (CC BY 4.0) license. Anyone may reproduce, distribute, translate and create derivative works of this article (for both commercial and non-commercial purposes), subject to full attribution to the original publication and authors. The full terms of this license may be seen

at: http://creativecommons.org/licences/by/4.0/legalcode

Vol. 9, No. 11, 2019, Pg. 1340 - 1359

Full Terms \& Conditions of access and use can be found at http://hrmars.com/index.php/pages/detail/publication-ethics 


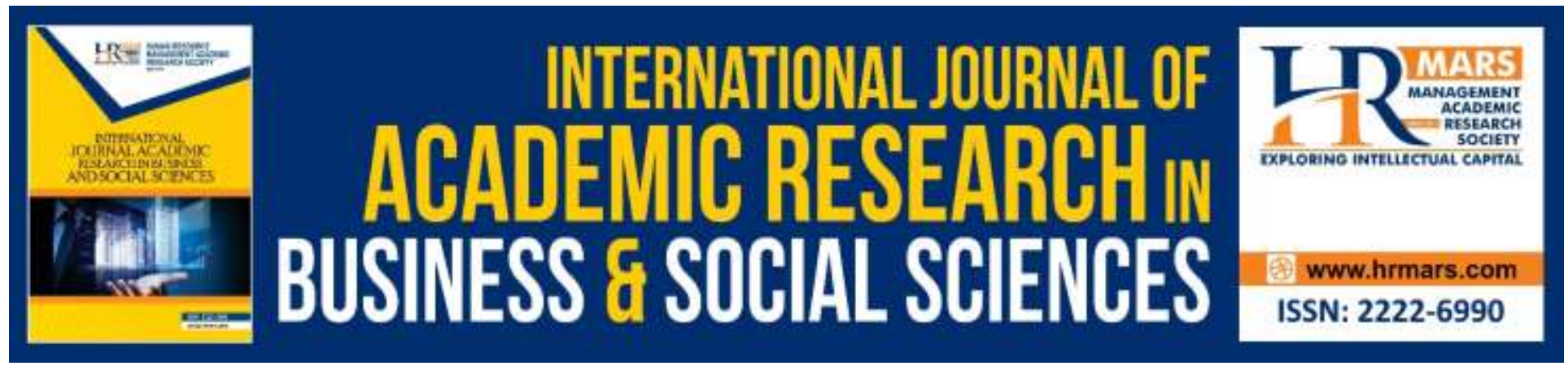

\title{
A Qualitative Case Study on Experiences of Universities and Industries Linkages in Nigeria
}

\author{
Ikechukwu Aloysius Odigbo \& Ismi Arif Ismail \\ Department of Professional Development and Continuing Education, Faculty of Educational \\ Studies, Universiti Putra Malaysia (UPM)
}

\begin{abstract}
Experience is seen as a fact or evidence of engaging in doing something e.g. learned a lesson in the classroom, work engagement experience and painful experiences such as a scene of difficulties in work-related activity or event. The experiences of the industries in the employability of graduates are widely explored to build on descriptive research approach geared to examine the employability skills close to the Nigerian context and linkages between universities-industries. The National Youths Service Corps experiences help graduates to know various kinds of industrial practices, work ethics, and integrate the importance of theoretical knowledge gained from the university and incorporate into industrial practice. Extra curricula training experience in university-industry linkages help graduates to perform very effectively and efficiently in some special skills. Internship and modern uses of technological experience help to advance career development in a particular environment and help to know the newest technologies relevant to the industry. This study recommends that universities and industries should enhance linkages among management boards, foster strategic plans and directions, collaborates on research, and create policies for the effective governance of industries linkages for promoting an important institutional approach to build industries linkages. Finally, Universities should improve in various strategies such as offering work experience, work-related learning and employability skills modules, ready for work events, as well as involving industry employers in course design and delivery.
\end{abstract}

Keywords: Universities, Industries and Graduates Experiences, and Linkages

Introduction

Experience records concurrently of business, organization and work-related encounter of individual life come into contact to meet his/her confrontation of work challenges and solutions. Experience is a skill or knowledge gain in a specific work activity engaged for a very long time or short period. Experience is seen as facts or evidence of engaging in a particular job, event, 
knowledge and feelings that make an individual life or character. According to Kolb (1984) defines experiential learning as a process of gaining knowledge created from the transformation of experience. The theory stated that results forms by creating and transforming the experience. Kolb's theory outlines four levels of experience as concrete experience, reflective observation, abstract conceptualization and active experimentation. Nigerian government has entered into various initiatives to enhance the framework for the development of science and technology (S\&T), and the initiative has linkages through public-private partnership (PPP), IT link with industry, and Entrepreneurship studies. The graduates' career engagement fosters high impact in the engagement of graduate to proactive and committed to the standard which will enable sourcing, attracting, retaining and engaging suitably qualified graduates into the work ethics. Industrial training foster to nurture, develop, manage, and gain a skilful graduate link with opportunities to industries and employ a resourceful industrial workforce. University links with the government to enhance sources of public funding to enable improvement in technology transfer and human training activities. University education is the process that details the need for training of skills; and the importance of the conceptualized dynamic characteristics; and benefits of acquiring more knowledge to enable the graduates to improve in the work-place and obtain job security in the labour market. The factors that enhance university and industry experience is the organizational structure of universities have been seen as essentials in the technology transfer performance Bercovitz et al., (2001). It was noted that geographical location also contributes to the development of linkages between universities and industries as an aspect of motivating factor. The quality of university education is the most essential issue for industries to engage with universities in the region Vedovello (1997); Laursen and Satler (2011). The issue of science and technology has gained momentum in enhancing competitive advantage in improving graduate entrepreneurial and employability skills and resolving specific requirement Wilson (2012). The curriculum framework mapped to address the issues of six core human resources development component is designed to be self-directed and self-paced, structured on an open entry; open exit basis to meet the people's needs such as research consistency which is the difference in aim and objective that focuses on industrial issues Dierdonck and Debacckere (1988); Ditzel (1998); Fassin (2000). Research in different organizational structure and policy has given attention to the industry that commercializes inventions rather than focuses on the issues relating to the university Caroline and Jeannette (2011). University education is a process that focuses on the training of employability skill and industrial work-related activities that enhance graduates' creativity of upholding potential strategic approach to job security and improved performance in the workplace. Michael and Alok (2002); Timothy et al., (2007) believes that the critical evaluation of the university and industry linking performance helps to evaluate, assess and determine individual competence on the job performance of graduates which tend to secure or currently holds a job.

\section{Aim and Statement of the Problem}

Experience is seen as facts or evidence of engaging in a particular job, event, knowledge and feelings that make an individual life or character. University-Industry linkage through 
Internships refers to a university student that engages to develop their skills in a particular industry within one-three months to enable the student to improve in the work opportunities. The universities have been consistently enrolling and turning out graduates in recent times meanwhile, most of these graduates have remained unemployed over year. Gabriel E.E, (2013) there is a need for partnership in the successful implementation of entrepreneurial education. African universities, especially Nigeria has been criticized of the poor state of the university and industry linkages; and universities are taking bold steps to maintain and accept means of providing and strengthening institutional ability to support linkages with industry and expand their productive sector Ginies and Mazurelle (2010); Timyambe (2004). However, there is a vacuumed over the experiences possessed by Nigerian graduates which are attributed to lack of basic training capacity, the deficit in infrastructure and poor funding of Nigerian universities. The linkages between National Directorate of Employment (NDE) with universities and industries are very important link to broaden the range of their demand and supply in the labour market, organized and analyzed information to enhance effective communication and collaboration with other graduates' experiences of diverse capacities, skills and competencies in the industries. Therefore, the current research looks into the industry and university experience in linkages on how educational training affect the employability of Nigerian graduates in the workforce and tend to address it.

\section{Research questions}

1. What experiences graduates should acquire to function well in the labour market?

2. How do universities and industries experiences relate to employability?

3. How do university and industry linkages strategies?

\section{Literature Review}

The researchers would establish valid questions that have not been explained in the previous literature that connects with university education and graduates industrial work experience. University education boards should enhance and introduce graduate career development and industrial linkages to foster productivity in the workplace.

\section{Conceptual Framework}

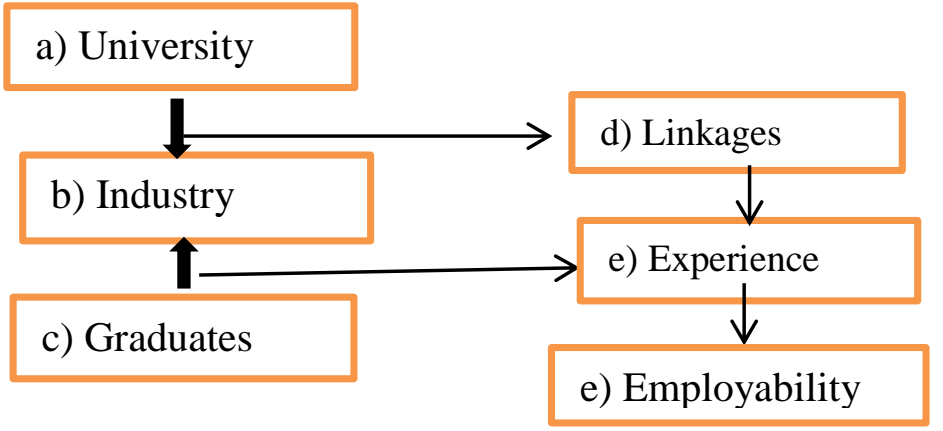

Figure 2: 1 Conceptual Frame Work and Purpose for the Study 
This study is based on existing research of collaborative theory of employability proposed by Aloysius el at., (2018). The universities and industries linkages were strategized to bridge the gap on scope and scale of industry placement programs and how levels of mobility between university research and industrial sector explain to employers need to be open to collaborative and share expertise. The University provides professional development courses to improve core competencies, enhance job performance, and encourage personal growth for university graduates and their employer's. The linkages between universities education and industries encourage important work experiences, enhancing graduates' motivation and development of the core skills, technical skills, and good qualities. Graduates learn new skills, training and new technological induction to focus on what is traditionally been known as education. Employability development includes: the development of employability attributes; work experience; the development of self-promotional and career development and management skills; a willingness to learn and reflect on learning. The ability of industries to use their technologies and innovate, forcing industries to seek out other industrial adaptations. Experience is seen as facts or evidence of engaging in a particular job, event, knowledge and feelings that make an individual life or character. Work Experiences help graduates to be exposed, and discover some important future career development to enhance professionalism in decision making, networking and gain employment.

\section{Graduate Career Development}

Graduate career development forms the part and parcel of human resource development aim at developing people and assisting industries to attract, develop and retain graduates. Filipinos et al. (2013); Allen et al., (2009); and Aloysius et.al. (2018) stated that career development and enhancement is anchored on some special qualities such as traits, social skills, personal attributes, and technical knowledge seen as a degree of qualifying to enhance training and career development. The privilege for graduates to envisage in the industries are very essential types of career development through extra training experiences and work placement that can enhance graduates to be prospective and future-oriented professional or expertise in technical works based on the positive choice and authentication of understanding of various occupations Mann et al., (2016); Baker Dearing Educational Trust (2017). According to Aloysius I. O (2013) stated that empowerment refers to the enhancement of graduates' autonomy for decision makings. The study stipulated that empowering of graduates enhance personal qualities such as responsibility, self-confidence, self-control, social skill, honesty, integrity, adaptability, flexibility, team spirit, punctuality, efficiency, self-directedness, good work attitude, good grooming, cooperation, self-motivation and self-management. Lubitsch and Smith (2007) stipulated that there is a need to change from psychological contract to job security to promote good job relation among the skilful job seekers and sustain through career development experience to enhance good performance towards effective and efficient means of talent experts. Sual, Lakewood and David (2015) stipulated that talent development has increased in terms of training of human resource development, improved performance, innovation, learning and development, workplace learning and performance has integrated into talent development 
sustainable management skills to foster graduates or individual team and industrial development. According to Aloysius, Ismail, Suandi, and Arshad, (2018) university provide professional development courses to improve core competencies, enhance job performance, and encourage personal growth for university graduates and their employers.

\section{Graduate Experience and Engagement in the Industry}

The increase of global workforce has brought about mobility and perception of the employers on employability issues, expecting more than required from employees. This issue of employability is focused on the industry to adopt into a business investment plan to enhance graduates" engagement and foster quality improvement. The employability in the industry really requires graduates who are psychologically enhancing work-related activities towards work role in the industries. According to Aloysius I. O (2019) employability development includes the development of employability attributes; work experience; the development of self-promotional and career development and management skills; a willingness to learn and reflect on learning. Edge Foundation (2017) stated that it is a very essential criterion for curricula and qualification engender to foster graduates access for conceptual, theoretical, and technical skills learning that tailored on creativity and technological innovation that would be used to retain a potential applicant in the industry. The graduate's career engagement fosters high impact in the engagement of graduate to proactive and committed to the standard which will enable sourcing, attracting, retaining and engaging suitably qualified graduates into the work ethics. Aloysius, Ismail, Suandi, Arshad (2018) stated the collaboration between graduates' engagement and employability skill has indicated a high level of engagement to really perform better than the ones with small or low engagement. Busby et al., (1997) stated that placement appraisal in tourism management among graduates require experience, accept responsibility, greater maturity, self-confidence, diagnosis and give solution to problems, develop attitudes and career aspiration.

\section{Graduates Industrial Training}

Industrial Training is a program that helps graduates to learn particular skills or gain a specific knowledge that will improve the performance of graduates in securing future or already made job opportunities, industrial rule and regulation at different advantages of fostering training and development. Edge Foundation (2017) stated that it is very essential to enhance good curriculum and qualifications that ensure that graduates quality access conceptual, theoretical and technical training that foster on creativity and innovation. Industrial training foster to nurture, develop, manage, and gain a skilful graduate link with opportunities to industries and employ a resourceful industrial workforce. Past literature shows that experience in industrial training may be determined by the kinds of individual perception, organizational attributes and industrial training on student generic skills development Leornard and Kenneth (1999); Martin et al. (1999); Nill and Schibrowsky (2005); Rolf et al., (2009) ; Kuritz and Hillsman (2011); Smith and Hume (2005). Industrial training is a very essential business proposal interested in constant training and practice that are effective and efficient to engage graduates in on-job 
training that would make graduates to have strong decision making into the industrial culture and mainly rely on human resource management activities. Watts (2006) stipulated that career development and learning were not fully represented at the university education and employability operation, and the main contending factors in the management development comprise of promotion for internal. Busby et al, (1997) stated that the industry should enhance adequate supervision for the task assigned to industrial training. Jackson (2015) argues that collaboration exists in the work experience and employability are based on industry value of graduates who have anticipated in the work experience programs and responses from graduates /student will determine his/her activeness in the work placement programs by identifying the kind of work experiences that will give graduates room or opportunities to enhance solid knowledge based on learning formal classroom condition.

\section{University versus Industry Linkages}

It is very important to give opportunities to graduates' attachments and placements in the production industry as means of universities link up with industries Homma and Attalage (2008); Munyoki et al. (2011). The Nigerian universities were seeking to establish a very strong link between professional skill training and employer's in the local industries through expertise to help shape, update and advance school curriculum course design. TETFund Act of 2011 was introduced in Nigeria to administer and disburse the fund from Federal and State Educational Institution for provision and maintenance of infrastructure for teaching and learning, material and equipment, research and publication, staff training and development, improvement of quality and maintenance of a high standard of educational institutions. University and industry linkages are of different kinds and include different varieties of engagement such as $R$ \& $D$, training and curriculum development, and consultancy Martin (2000). Universities aimed at enhancing consultancy and business-related service e.g. Test and certification Basant and Chandra (2007). National System of Innovation NSI (1997) frame stipulated that innovation involved the collective process of industry-university linkages; create research centres, government agencies support and other stakeholders Goransson and Brundeius (2011). NIS model consists of economic and institutional structures of countries that contribute to the development and diversify the use of innovation Edquist (2004). University and industry enhance linkages among management board, foster strategic plan and direction, collaborate on research, create policies for the effective governance of industry linkages for promoting an important institutional approach to build industry linkages Kruss (2008). The vision of enhancing highquality university teaching and research through foreign recognized university education, which in turn produce graduates with the skills required for local and regional industries, is divided by all national education reform (International Trends in Higher Education 2016-2017). University education was inviting an industrial representative from the different organization to participate actively through formal structures and committees which will help coordinate high ethical status quo in professional and personal life which will undergo for the personal ability of self-directed activities and learning. The industry contributes to defining graduate student research projects that anchor on the factors and challenges of direct interest to industry Boersmaa and Gibbons 
(2008). There is a critical situation in university educational training in Nigeria and universities should collaborates in both their school curriculum to be both technical and core skill acquisition to enable graduates /student cope with current workforce demand, acquire core training and skill requirements needed by industries and workforce at large. University support to promote linkages, set up industrial liaison offices, technology transfer offices, technical and business inventive, establish entrepreneurial and Employability Centre, and science part on campuses to enable dissemination of information such as interaction Lundvall (2009).

\section{Graduates Transfer from University to the Industry}

The conjuncture of time and strategizing individual graduates were in collaborating with training, learning, and the characteristics of the universities educational system which influence and determines the kind of and levels of competences required and acquired by graduates; and expected from their employer's in the industry. This has attracted increasing interest among many researchers who look into the education to work transition of new graduates (Jackson, 2016). The positive impact is the result of modification and change based on experiences of graduates at the university, for example, workplace salary, internship, association and participation of university politics. The competences development encountered during graduation based on the importance of workplace collaboration with experiences after completing the study. The benefit of workplace experiences on the competencies will be exploring to the nature of work task collaboration with the knowledge management, training, learning and work-related activities. The knowledge management experiences are determined by effect and also influenced by the approaches industries is related to accept the demand of their employees. Therefore, skill mismatches imply the capacity of industries to enhance technologies and innovation, influencing industries to look into industrial adaptions. The skills embedded into investment in human resource development, which has become the emergent issues of innovation Estevez-Abe, Iversen, \& Soskice (2002).

\section{Industry Skills Requirement}

There is need of constant learning or lifelong learning as the key of employability among graduates and recommended the following skills to be incorporated as skills required in the workforce such as networking, teamwork, persistence, organization skills, risk-taking, optimism and flexibility is seen as very essential potential and qualities graduates should possess. According to Suleiman (2016); Olivier et al. (2014); and Aloysius et.al., (2018) summarized that skills needed by every industry are regarded as essential skill is required by industrial employer such as foundation skills that are based on theoretical and practical aspect of resolving the emerging skill enhancement and integrated into the system. Aloysius, I.O (2019) stated that employability skills industries were looking for are as follows: Communication skills, Teamwork, Problem solving, Initiative and entrepreneurial skills, Planning and organizing, Self-management, Lifelong learning and adaptability, Technologies such computer skills, information technology skills, and ex-training at work; Leadership skills, Perseverance and motivation. The technical and soft skills should be considered very essential among graduates that will give them an open door 
to enter in university career development to begin to develop career specialization when they have employment.

Woldegiorge et al. (2015), as well as Babes (2009), were of the opinion that globalization is the major economies that were engaged in acquiring substantial learning anchored on denotative knowledge that will emancipate the kind of acquiring skill in education, training, development of lifelong learning, and innovation. Wilson (2012) stated the importance of work placement, work experiences, internships and industry's initiative based on developing the relevant skills and potential required in the labor market for employment. Employability skills among graduates maybe seen or predicted, if the important requirement for recruitment exercise is lacked, meanwhile the unemployed graduates with little hope of looking and finding a job will be considered in less welfare and will struggle to survived, while employed graduates with highly employed skills will gain more income and will have job security Aloysius et. al., (2018). Creasy's (2013) explained and collaborates with this approach by indicating that the industry's want graduates with good educational background such as (content) demonstrative skill (capability) and personal attributes (character). The major transition is from student to entrepreneurial engagement and business advancement is to meet the need of organization want.

\section{Method / Materials}

According to Vickie and Clinton (2012), a qualitative descriptive approach needs to be the design of choice when a straight forward description of a phenomenon is desired. Parahoo (1997) stated that a research design is a plan that describes what, how, when and where data is collected and analyzed. Thus, this study focuses on target group such as graduates, Universities and Industries in the southeast of Nigeria; and the data generation approach involves typical individual or focuses group interviews with an inquiry of semi-structured guides. The management of faculties form the first participants as category (A), human resource management of Nigeria Industries form the second participants as category(B) and employed graduates from the third participants as category (C). The transcripts were analyzed in two stages: Stage 1 - a thematic analysis form the underpinning issues raised within the interview. Therefore, the experiences of the industry in the employability of graduates are widely explored to build on descriptive research approach which gear to examine the graduates experience close to the Nigerian context and linkages between university-industry contexts.

\section{Sampling Strategies}

According to Vickie and Clinton (2012) the use of sampling in a qualitative descriptive design, virtually any purposeful sampling technique may be used and other qualitative research design, the goal is to obtain cases deemed rich in information for the purpose of saturating the data. 


\section{Participants of the Study}

The major participants of the study were a total number of twelve; four members of employed graduates, four members of university management of faculties at universities and four members of industrial managers of Nigerian Industries. The selection criteria of these three (focus group) informants were based on the focus of the research ethics, to enable the researcher to get the in-depth by the live experience of the participants such as graduates, university's management of faculties and industry's managers.

Table 3:2 Categorizations of Informatics

Category / Descript of Informatics / Status / No of informants.. Contributions for RQ

$\begin{array}{lllll}\text { A } & \text { University Participants } & \text { Dean of Faculties } & 4 & 1,2,3 \text { \& } 4 \\ \text { B } & \text { Industry Participants } & \text { Industry Managers } & 4 & 1,2,3 \text { \& } 4 \\ \text { C } & \text { Graduates Participants } & \text { Employed Graduates } & 4 & 1,2,3 \text { \& } 4\end{array}$

Total Number of Participants

12

\section{Data Analysis}

The data analysis was elaborated because it was descriptive and the focal point of every research design. The process started during the time interviews were conducted until data saturation emerges. The transcription of the interviews was analyzed adopting interview protocols, ethics and text language to enhance good findings to the experiences of university and industry linkages in employability skills Nigerian graduates should possess at the workforce. Immediately after the data was transcribed, and coded, the researcher analyzed, interpreted and verified. The act of transcribing the interviews would assist the study to enhance good understanding of the research from the perspective of listening and reading the transcription of the interviews on the perspective of university-industry experience in linkages and employability of Nigerian graduates. Field and Morse (1996) stated that data analysis help to identify an individual that plays a major role such as understanding, synthesizing and theorizing. The act includes a process of checkmating validity by relooking into the transcribed words and emergent sub-themes again to know if the researcher has really verified or modified the interview research questions to suit the previous amendment as was advised by reviewer members. The researcher was recommended to look into the experiences of the entire university-industry representative and employed graduate participants, and the researcher engaged again with all the participants to ask a question of their experiences in the work-place and problem encountered. Qualitative descriptive design is applied to describe what, how, when and where data is collected and analyzed. Thematic analyses help to comprehend the individual experience of fact or reality in a deep explanation to get an in-depth understanding of the phenomenon in question. The theme is arranged into categories/subcategories from most prevalent to the least prevalent themes and sub-themes 


\section{Discussions and Findings}

There is recognition of the full range of benefits to be gained from both 'work-based' practice and work-related' experience; this will strengthen the overall employability provision for the graduates. Live design briefs, industry competitions, case studies, simulations, role plays, discussions, presentations, workshops, Industrial training, internship, and mentoring, etc. are all ways to involve industries directly with graduates/ student on campus. The activities available at the university should support graduates' personal development beyond the curriculum.

\section{Experiences Graduates Should Acquire to Work Effectively}

There is a series of training that will foster graduate experience to enable them to familiarize with work ethic in the labour market. Universities in Nigeria link with industries through different programs such as computer training skills, entrepreneurial training, student industrial work experience scheme, and after graduation graduate is sent to (NYSC) National Youth Service Corps.

"Aisha"-Industrial training foster to nurture, develop, manage, and gain a skilful graduates link with opportunities of industries to employ a resourceful industrial workforce.

Past literature shows that experience in industrial training may be determined by the kinds of individual perception Leornard and Kenneth (1999); Martin et al. (1999); Nill and Schibrowsky (2005); Rolf et al., (2009) and organizational attributes Kuritz and Hillsman (2011); Smith and Hume (2005). The aim of the employability action plan is to provide a simple record of each departmental area of specialization that can be potentially shared internally and externally as appropriate and used to target further support and resources where needed. Green et al. (2013) stated the importance of employability and it similarities of the major employability frameworks, adding to support the system to structure newly reviewed employability framework that enabling support factors seen as individual factors like circumstances; such as industrial practice; (SIWES) or internship, on job training and workshop or seminar at local contextual factors and macro-level factors. Internships refer to a university student that engages to develop their skills in a particular industry within one-three months to enable the student to improve in the work opportunities. Therefore, the maximum experiences gained from work are required for close communication between the University Centre for Employability and will increase industrial demand in the curriculum development and training Chillas et al., (2015).

"Emma" Industrial training in Nigeria or SIWES (Student Industrial Work Experience Scheme) was established to enable graduates to acquire some work experiences before graduation. The (SIWES) help graduates to be exposed, and discover some important future career development to enhance professionalism in decision making and networking. It is exposure and opportunity to help graduates explore into the industrial work experience and do the practical aspect of what is learnt in the university. 
Jackson (2015) argues that collaboration exists in the work experiences and employability are based on industry's value of graduates who have anticipated in the work experiences programs and responses from graduates /student will determine his/her activeness in the work placement programs. National University Commission was introduced to foster qualitative education, develop student positive attitudes, and improve the economy, technological and industrial development in Nigeria (NUC) 2007.

"Aliyu" Graduates experiences refer to the work-related activities that will enhance improvement in the industry. This refers to engagement such as university-industry training collaboration that helps to train graduates in some special skills or work-related training. It is an encounter that will expose graduates to the world of work such as on-job training, IT or internship, workshop, and seminar.

It is important to note that work placement, work experiences, internships and industrybased initiative help graduate to transfer some relevant skills acquired from the university to the labour market for employment. Therefore, there is a transfer of those skills graduate has learnt from the universities to the world of work. This study focused on exploring the industry's and university's experiences in education and employability among Nigerian graduates in the workforce. Wilson (2012) stated the importance of work placement, work experiences, internships and industry's based initiative that is anchored on developing the relevant skills and potentials required in the labour market for employment. This study defines experience as an observation of what happens in real life and has to do with practical encounter derived from participation or engagement in something.eg. work experience, and graduates IT experience. The findings show that experience graduates should possess to function well in the labour market is below:

Table 4.1: Experience Graduates Should Acquire to Work Effectively in the Industries

1. IT experience during studentship at the university gives an important practical exposure, skills and assists in becoming a successful professional IT graduate with good work attitudes.

2. NYSC experience helps graduates to know various kinds of industrial practices, work ethics, and integrates the importance of theoretical knowledge gained from the university and incorporates into practice.

3. Extra curricula training experience in university-industry training help to enhance effective and efficient graduates in some special skills. 
4. Internship/modern uses of technological experience help to advance career development in a particular environment and help to know the newest technologies relevant to the industry.

5. Workshop training and Student Industrial Work Experiences Scheme (SIWES) were meant to prepare both graduates and undergraduates to be familiar with industrial work and acquire competence.

6. Work induction experience to adapt to industrial rule and regulation at different advantages of fostering training and development to enable graduates acquired excellent work practice.

7. On-job training experience foster to nurture, develop, manage, and gain a skilful graduates link with opportunities of industries to employ a resourceful industrial workforce.

\section{Universities and Industries Experiences Relating to Employability}

There is a link which exists among employability of university graduates and that of industrial training; learning through different extracurricular activities, graduates ought to acquire in the university programs Sumanasiri et al. (2015).

"Alex "University and industry experience are the most essential part of career development and growth. Industrial training is a very essential business proposal interested in constant training and practice that are effective and efficient to engage graduates in on-job training that would make graduates to have strong decision making into the industrial culture.

The privilege for graduates to envisage in the industries are very essential types of career development through extra training, work experiences and placement that can enhance graduates to be prospective and future-oriented professional. Benson et al., (2013) stated that social skill and inherent personal traits are more essential that technical or a degree qualification as results of these traits are pivotal to enhance training and career development.

"Aliyu" industrial work experience scheme was established to enhance the linkage between university and industrial collaboration for three to six months to prepare the graduate/student to be familiarized with the industrial job and integrated what they have learnt in the university to the world of world.

The (SIWES) is a very important future of career development to enhance professionalism in decision making and networking. It gives the opportunity to help explore the industrial work experience and do the practical aspect of what is learnt in the university. It helps to gain a 
placement and retained graduates after (SIWES) program to form part and parcel of the Nigeria Breweries. Nairn and Panelli (2009); Jorri n-Abella n' et al., (2008); Francis, Ong'ayo \& Adams (2018) has looked into the vicarious experience as effective to support the description of the context. However, through the research investigations and responses from informants' interview identifies how universities and industries experience relating to employability are as follows:

- Universities and industries share a responsibility to prepare graduate student to be familiarized with an industrial job and integrated what they have learnt in the university.

- Universities and industries experiences are the most essential part of career development and growth.

- The privilege for graduates to envisage in the industries are very essential types of career development through extra training, work experiences and placement that can enhance graduates to be prospective and future-oriented professional.

- It's embedding the development of employability skills into universities curriculum and linkages to industrial work experience.

The finding of this study was supported by previous studies by Jackson (2015) argues that collaboration exists in the work experiences and employability is based on the industrial value of graduates who have anticipated in the work experiences programs. Contextual factors influencing work experience and learning facilitation Ellinger and Cseh (2007), it examined the means of indicating self-efficiency, outcome expectation, and identify input aligned with contextual factors collaborated with job experience and satisfaction.

\section{Universities and Industries Linkages Strategies}

Universities and industries linkage have different kinds and includes different varieties of engagement such as R \& D, training and curriculum development, and consultancy Martin (2000). University and industry have liaised together to boost industrial based research whereby the research will be carried out at a particular industry. Nigerian universities have formed various kind of partnership, private partnership, IT link with industry, and entrepreneurship studies.

"Lili" Nigerian government has entered into various initiatives to enhance the framework for the development of science and technology (S\&T), and the initiative has linkages through public-private partnership (PPP), IT link with industry, and Entrepreneurship studies. University links with the government to enhance sources of public funding to enable improvement in technology transfer and human training activities. 
The scope and scale of industrial placement programs show how levels of mobility ensure universities and industries research sectors explain to employers the need to be open to collaborate and share expertise opportunities. Universities aim at enhancing consultancy and business-related service e.g. test and certification Basant and Chandra (2007). National System of Innovation NSI (1997) frame stipulated that innovation involves a collective process of industry-university linkages, create research centres, government agencies support and other stakeholders Goransson and Brundeius (2011); Kasasbeh (2018). NSI model consists of the economic and institutional structure of a country that contributes to the development and diversifies the use of innovation Edquist (2004).

"Tracie," Nigerian universities have linkages with industries through (SIWES) programs, whereby every undergraduate's student in Engineering or sciences in Nigerian universities have to go for student industrial work experience scheme programs at their 300 level.

Past studies indicated that many Nigeria universities lack material resources and expertise to manage industry and university linkage in technological transfer effectively; few universities in Nigeria engage in the transfer of knowledge through university and industry linkages Jansen (2002); Adeoji (2009); Munyoki et al., (2011). However, graduates can equally link between the theory and practical, but it was not well utilized, harmonized and administered because of inadequate linkages between universities- industries. Education is used to play a vital role in many ways for improving human capital development, enhance industrial productivity, foster livelihood of people, embrace new technologies, create parents and citizenship awareness, attitudes, skills and encourage linkages among regional and global development, curb economic, social and environmental challenges Birger and Ruth (2013).

"Aisha" Industrial experiences in training, foster to nurture, develop, manage, and gain a skilful graduates link with opportunities of industries to employ a resourceful industrial workforce. There are various kinds of training that will foster graduate experience to enable them familiarized with work ethic in the labor market such as extra curriculum training, on-job, IT training, internship, and workshop. Universities in Nigeria link with industries through different programs such as computer training skills, entrepreneurial training skills, student industrial work experience scheme and (NYSC) National Youth Service Corps.

Gibson (2014) who proposed that ELVIS model of employability was institutionalized to anchor on employability for collaborating university education system, business enterprises and ecosystem; admiring resources value, invention and innovation approach, Student Centre for Employability and Entrepreneurial Development. The study findings are as follows:

- The study indicates that universities enhance employability skills in their curriculum, but most of their teaching is based on theory due to lack of government funding on education, 
lack of support in technological skills development and there is no new current trend on infrastructural development among universities.

- The study shows that there is an enhancement between university and industry in Nigeria regard to the share of the partnership in IT and entrepreneurial training, but the enhancement was not well collaborated.

- The study identified inadequate linkages among universities management and industrial employer to share expert knowledge.

Evers et al. (1998) said that university education should link with the industry by adopting the important support measure that will enable skill equipment facilities to enhance good qualitative education in general that would enhance employability skills into the academic curriculum. The link between industries and universities was established by enhancing some research Centre in some of the universities to collaborate with undergraduates to enable them to enhance their qualities and acquire a skill that will help them to function well in the labor market. The best option of enhancing skills requirements is through linkages between industry and university collaboration which depends on the kind of activity or other benefits of collaboration that can be enriched between the two bodies such as: reducing costs, using a multidisciplinary approach, collaborators reputation, experts in a particular field Draghici et al., (2015).

\section{Conclusions and Recommendations}

Universities in Nigeria link with industries through different programs such as computer training skills, entrepreneurial training, student industrial work experience scheme, and after graduation graduate is sent to (NYSC) National Youth Service Corps. The National Youths Service Corps experiences help graduates to know various kinds of industrial practices, work ethics, and integrate the importance of theoretical knowledge gained from the university and incorporates into practice. Industrial Training experience during studentship at the university gives an important practical exposure, skills and assists in becoming a successful professional IT graduate with good work attitudes. Extra curricula training, Internship and modern uses of technological experience help to advance career development in a particular environment and help to know the newest technologies relevant to the industry. Workshop training and Student Industrial Work Experiences Scheme (SIWES) were meant to prepare both graduates and undergraduates to be familiar with industrial work and acquire competence. On-job training experience foster to nurture, develop, manage, and gain a skilful graduates link with opportunities of industries to employ a resourceful industrial workforce. The study shows that linkages between National Directorate of Employment (NDE) with universities and industries are very important link to broaden the range of their demand and supply in the labour market, organize and analyze information to enhance effective communication and collaboration with other graduates of diverse capacities, skills and competencies in Nigeria. Therefore, the experiences of the industry 
in the employability of graduates are widely explored to build on descriptive research approach which gear to examine the employability skills close to the Nigerian context and linkages between university-industry. Moreover, there are universities and industrial linkages in student industry training attachments, but the linkage was not synergized to enhance good performance. The university and industry linkage is embedded in the school curriculum, but the linkages are not strategized because of infrastructural problem to make practice. Exclusively, universities experiences are lack of government inadequate support such as funding, and Industries experiences are lack of inadequate linkage in Industry Training attachment. This study recommends that universities and industries should enhance linkages among management boards, foster strategic plans and directions, collaborates on research, and create policies for the effective governance of industry linkages for promoting an important institutional approach to build industry linkages. Finally, Universities should improve in various strategies such as offering work experiences, work-related learning and employability skills modules, ready for work events, as well as involving industrial employers in course design and delivery.

\section{Corresponding Author}

Ismi Arif Ismail (PhD), Department of Professional Development \& Continuing Education, Faculty of Educational Studies, Universiti Putra Malaysia, 43400 UPM Serdang, Selangor Darul Ehsan, Malaysia.

Email: ismi@upm.edu.my

\section{References}

Aloysius, I. O. (2013). Perception of Empowerment among International Students at the University Putra Malaysia. International Journal of Business and Management, 8 (23), 2013 ISSN 1833-3850, E-ISSN 18338119, Published by Canadian Centre of Science and Education.

Aloysius, O. I., Ismail, I. A., Suandi, T., \& Arshad, M. M. (2018). Enhancing University's and Industry's Employability Collaboration among Nigeria Graduates in the Labor Market. International Journal of Academic Research in Business and Social Sciences, 8(7), 32-48.

Aloysius, I. O. (2019) Exploring University and Industry Perceptual Meaning of Employability Skills among Nigerian Graduates. International Journal of Educational Science and Research (IJESR) 9 (1), Feb 2019, 21-36 issn (P): 2249-6947; ISSN (E):2249-8052

Benson, Morgan, \& Filippaios. (2013). Social career management: social media and employability skills gap. Computers in Human Behaviors, 30, 519-525

Basant, Rakesh, \& Chandra, Pankaj. (2007). "University-Industry Linkages and Enterprise Creation in India: Some Strategic and Planning Issues" in How Universities Promote Economic Growth. Washington: World Bank

Babes. (2009). Algeria towards a knowledge-based economy: developing knowledge economy strategies to improve competitiveness. Alexandria, Egypt: World Bank Development Institute. Graduate Employability Skills: Differences between the Private and the Public Sector in South Africa. 
INTERNATIONAL JOURNAL OF ACADEMIC RESEARCH IN BUSINESS AND SOCIAL SCIENCES

Vol. 9, No. 11, November, 2019, E-ISSN: 2222-6990 @ 2019 HRMARS

Boersma, F. K., Reinecke, C., \& Gibbons, M. (2008). Organizing the university-industry relationship: a case study of research policy and curriculum restructuring at the NorthWest University in South Africa

Busby, G., Brunt, P., \& Baber, S. (1997). Tourism sandwich placements: an appraisal. Tourism Management, 18(2), 105-110

Bercovitz, J., Feldman, M., Feller, I., \& Burton, R. (2001). Organizational structure as a determinant of academic patent and licensing behavior: An exploratory study of Duke, Johns Hopkins, and Pennsylvania State universities. The Journal of Technology Transfer, 26, 21-35.

Creasey, R. (2013)."Improving Students' Employability." Engineering Education 8 (1), 16-30.

Chillas, S., Mark, A., \& Galloway, L. (2015). Learning to labour: An evaluation of internships and employability in the ICT sector. New Technology, Work and Employment, 30(1), 1-15

Dierdonck, V. R, and Debackere, K. (1988), Academic Entrepreneurship at Belgium University, $R \& D$ Management, 4, 77-91.

Ditzel, R. G. (1988), Patent Rights at the University/Industry Interface. Journal of Social Research Administration, 1, 221-229.

Draghici A., Ivascu L. V., Baban C. F., \& Bacall L. (2015a). University-Industry Collaboration in Open Innovation, Proceedings of 9th annual International Technology, Education and Development Conference, INTED 2015, 2nd - 4th of March 2015, Madrid, Spain, 6278 6287. Retrieved from http://library.iated.org/view/DRAGHICI2015UNI

Ellinger, A. D., and Cseh, M. (2007) Contextual factors influencing the facilitation of others' learning through everyday work experiences. Journal of Workplace Learning, 19(7), 435452

Ellinger, A. D., \& Cseh, M., (2007) Contextual factors influencing the facilitation of others' learning through everyday work experiences. Journal of Workplace Learning 19(7), 435- 452.

Evers, F. T., Rush, J. C., \& Berdrow, I. (1998). The bases of competence. Skills for lifelong learning and employability. San Francisco: Jossey-Bass

Fassin, Y. (2000), The Strategic Role of University-Industry Liaison Offices. Journal of Social Research Administration, 2, 142-160.

Gabriel, E. E. (2013). Transformation of University Education for Graduate Employability in Nigeria: The Intervention of Entrepreneurship Education

Gibson, D. (2014). Enterprise Education: Making It Happen.

York:/Higher/Education/Academy/Event.heacademy.ac.uk/events/

Detail/2014/25_march_leaders_emp

Goransson, B., \& Brundenius, C. (2011). Universities in Transition: The Changing Role and Challenges for Academic Institutions. New York: Springer

Homma, H., Ikeda, H., \& Attalage, R. A. (2008). "Strengthening University-Industry Linkages in Developing Countries Through International Cooperation: Case Study of Sri Lanka Through Cooperation of Toyohashi University of Technology, Japan" in Innovation Techniques in Instruction Technology, E-learning, E-assessment and Education. Springer Science and Business Media B.V. 
Jorrín-Abellán, I. M., \& Stake, R. E. (2009). Does Ubiquitous Learning Call for Ubiquitous Forms of Formal Evaluation?: An Devalued oriented Responsive Evaluation Model. Ubiquitous Learning: An International Journal, 1(3), 71-82.

Leonard, K., and Kenneth, M. (1999). The lessons of work: toward an understanding of the implications of the workplace for adult learning and development. Journal of Workplace Learning, 11(6), 192-202.

Laursen K., Reichstein T., \& Salter A. (2011). Exploring the effect of geographical proximity and university quality on university-industry collaboration in the United Kingdom, Regional Studies.

Lundvall, B. A. (1988; 2009) "Innovation as an Interactive Process: From User-producer Interaction to the National System of Innovation", in Dosi, G., Freeman, C., Nelson, R., Silverberg, G. and Soete, L. (eds), Technical Change and Economic Theory, London: Pinter Publishers

Martin, M. (2000). Managing university-industry relations: A study of institutional practices from 12 different countries. A Working document in the series "Improving the managerial effectiveness of higher education institutions." Paris: International Institute for Educational Planning/UNESCO.

Munyoki, Justus, Kibera, Francis, and Ogutu, M. (2011). "Extent to which university-industry linkage exists in Kenya: A study of medium and large manufacturing firms in selected industries in Kenya" in Business Administration and Management, 1(4), 163-169.

Michael, D. S., and Alok, K. C. (2002), Firm Size and Technology Centrality in Industry-University Interactions. Research Policy, 31(7), 1163-1180

Nairn, K., \& Panelli, R. (2009). Fiction to Make Meaning in Research with Young People in Rural New Zealand

Nill, A., \& Schibrowsky, J. (2005). The Impact of Corporate Culture, the Reward System, and Perceived Moral Intensity on Marketing Students' Ethical Decision Making

Olivier. (2014) Employer Satisfaction Survey. Australia: The University of Sydney Business School, Report for the Department of Education. Graduate Employability Skills: Differences between the Private and the Public Sector in South Africa

Suleman. (2016). Employability skills of higher education graduates: Little consensus on a muchdiscussed subject. 2nd International Conference on Higher Education Advances, HEAd'16, 21-23 June 2016, València, Spain

Sumanasiri, Erabaddage, G. T., Mohd, S. A. Y., \& Ali, K. (2015). "Review of literature on Graduate Employability", Journal of Studies in Education, 2015

Smith, A., \& Hume, E. (2005). Linking Culture and Ethics: A Comparison of Accountants' Ethical Belief Systems in the Individualism/Collectivism and Power Distance Contexts. Journal of Business Ethics, 62(3), 209-220

Tiyambe, P. (2004). African Universities in the Twenty-first Century. Volume I: Liberalization and Internationalization. Dakar, Council for the Development of Social Science Research in Africa, CODESRIA, 2004; 350 p., 2-86978-125-3 
Timothy, L. K., Bruce, C., Lerzan, A., and Tor, W. A. (2007). The value of different customer satisfaction and loyalty metrics in predicting customer retention, recommendation, and share-of-wallet. Journal of Service Theory and Practice (Manag Serv Qual) Publisher: Emerald, 17(4), 361-384 · July 2007

Vickie, A. Lambert, C. E., Lambert. (2012). Qualitative Descriptive Research: An Acceptable Design. Pacific Rim International Journal of Nursing Research, 16(4), (2012): October December 2012

Volmink, J., \& Dare, L., (2005). Tec novation, 17(9), 491-502. Addressing inequalities in research capacity in Africa. British Medical Journal

Vedovello, C. (1997). Science parks and university-industry interaction: geographical proximity between agents as a driving force. Technovation, 17(9), 491-502, 530-531

Wilson (2012)."International Education and the Employability of UK Students. British Educational Research Journal, 38 (2), 281-298

Wei, Y; Jin, C., and Yaqi, S. I., (2011), Research on the knowledge Creation Process of the University-Industry Collaboration: A Case from China. African Journal of Business Management, 5(32), 12586-12597

Woldegiorgis, E. T., Petronella, J., Anne, G., (2015). Regional higher education reform initiatives in Africa: A comparative analysis with the Bologna process. International Journal of Higher Education, 4(1), 241-253 Graduate Employability Skills: Differences between the Private and the Public Sector in South Africa. 